\title{
Epidemiology and clinical course of acute gastroenteritis in the Department of Paediatrics, Paediatric Nephrology and Allergology in 2018
}

\author{
Epidemiologia i przebieg kliniczny ostrego nieżytu żołądkowo-jelitowego \\ w Klinice Pediatrii, Nefrologii i Alergologii Dziecięcej w 2018 roku
}

\author{
Department of Paediatrics, Paediatric Nephrology and Allergology, Military Institute of Medicine, Warsaw, Poland \\ Correspondence: Agata Wawrzyniak, Department of Paediatrics, Paediatric Nephrology and Allergology, Military Institute of Medicine, Szaserów 128,04-141 Warsaw, Poland, e-mail: awawrzyniak@wim.mil.pl
}

\begin{abstract}
Introduction: Rotavirus infection is the most common cause of acute diarrhoea in all European countries. In contrast, norovirus aetiology is becoming more common in countries where rotavirus vaccination has become a standard practice. Aim: The aim of the paper was to assess the aetiology and the clinical course of acute gastroenteritis in children hospitalised in the Department of Paediatrics, Paediatric Nephrology and Allergology of the Military Institute of Medicine. Materials and methods: Medical records of children hospitalised in the Department of Paediatrics, Paediatric Nephrology and Allergology of the Military Institute of Medicine in Warsaw between January and December 2018 due to gastroenteritis were analysed retrospectively. The study group included children diagnosed with acute gastroenteritis who had microbiological stool analysis performed. Results: Gastroenteritis of unknown aetiology was diagnosed in 93/155 children, rotaviral aetiology in 37, adenoviral aetiology in 7, and noroviral aetiology in 5 children. Stool culture was positive for Salmonella spp. in 5 children. Furthermore, mixed aetiology was found in 8 children (rotavirus/adenovirus in 5, and rotavirus/norovirus in 3 children). Rotaviruses were the most common aetiology of gastroenteritis among children aged $\leq 2$ years. Vomiting and diarrhoea were the only symptoms in 48 and 40 children, respectively. The symptoms co-occurred in 67 children. Increased C-reactive protein (CRP) was found in patients with adenoviral aetiology and Salmonella spp. infection. We observed statistically more common low CRP levels and increased aminotransferase levels in patient with rotavirus infection. Conclusions: Rotaviruses were the most common aetiology of acute gastroenteritis in the study group. The clinical picture of rotavirus infection is dominated by vomiting and diarrhoea, which are relatively often accompanied by transient hypertransaminasemia.
\end{abstract}

Keywords: acute gastroenteritis, children, rotavirus, adenovirus, norovirus, hypertransaminasemia

Wstęp: Najczęstszą przyczyną ostrej biegunki we wszystkich krajach europejskich jest zakażenie rotawirusowe. Natomiast w krajach, w których powszechne stały się szczepienia ochronne przeciw rotawirusom, częstsza staje się etiologia norowirusowa. Cel pracy: Celem pracy była ocena etiologii i przebiegu klinicznego ostrego nieżytu żołądkowo-jelitowego u dzieci hospitalizowanych w Klinice Pediatrii, Nefrologii i Alergologii Dziecięcej Wojskowego Instytutu Medycznego. Materiał i metody: Analizie retrospektywnej poddano dokumentację medyczną dzieci hospitalizowanych w Klinice Pediatrii, Nefrologii i Alergologii Dziecięcej Wojskowego Instytutu Medycznego w Warszawie w okresie od stycznia do grudnia 2018 roku z powodu nieżytu żołądkowo-jelitowego. Do grupy badanej kwalifikowano dzieci z rozpoznaniem ostrego nieżytu żołądkowo-jelitowego, u których wykonywano badania mikrobiologiczne kału. Wyniki: U 93/155 dzieci stwierdzono nieżyt żołądkowo-jelitowy o nieustalonej etiologii, u 37 - etiologię rotawirusową, u 7 - adenowirusową, u 5 - norowirusową. U 5 dzieci w posiewie kału wyhodowano Salmonella spp. Ponadto u 8 dzieci stwierdzono etiologię mieszaną (u 5 rotawirusową i adenowirusową, a u 3 - rotawirusową i norowirusową). Wśród dzieci do 2. roku życia najczęstszą etiologię nieżytu żołądkowo-jelitowego stanowiły rotawirusy. U 48 chorych jedynym objawem były wymioty, u 40 - biegunka, natomiast u 67 badanych objawy współwystępowały. Podwyższone stężenia białka C-reaktywnego (CRP) stwierdzano w przypadku zakażenia o etiologii adenowirusowej i w przypadku zakażenia bakteryjnego pałeczką Salmonella spp. Zaobserwowano, że w przypadku zakażenia rotawirusowego statystycznie częściej obserwowane są niższe wartości CRP i wyższe wartości aminotransferaz. Wnioski: Najczęstszym czynnikiem etiologicznym ostrego nieżytu żołądkowo-jelitowego w badanej grupie dzieci były rotawirusy. W obrazie klinicznym infekcji rotawirusowej dominują wymioty i biegunka, którym stosunkowo często towarzyszy przejściowa hipertransaminazemia. 


\section{INTRODUCTION}

A cute gastroenteritis is defined by the European Society for Paediatric Gastroenterology, Hepatology and Nutrition (ESPGHAN) and the European Society of Paediatric Infectious Diseases (ESPID) as a change in stool consistency to liquid or semi-liquid, and/or an increase in frequency of bowel movements (three or more stools per day). Infectious diarrhoea is usually accompanied by other symptoms, such as vomiting or fever. The duration of acute diarrhoea is usually less than 7 days and not longer than 14 days $^{(1,2)}$.

According to ESPGHAN estimates, the incidence of acute diarrhoea in European children $\leq 3$ years old is $0.5-2$ episodes per year. Rotavirus, group A rotavirus in particular, is the most common cause of acute diarrhoea in all European countries (hospitalisation rates 7-81\%). Peak incidence is observed between January and March. In contrast, noroviral aetiology is becoming more common in countries where rotavirus vaccination has become a standard practice (hospitalisation rates $10-15 \%)$. Viral aetiology of acute diarrhoea is significantly more common in infants compared to children $>2$ years of age $e^{(1-4)}$.

Bacterial infections are less common and mainly detected in children $>2$ years of age. Most of these infections are caused by Salmonella spp. and Campylobacter spp. New cases are recorded throughout the year, with peak incidence in May, June, September, and October ${ }^{(1-4)}$.

Also, infections caused by Clostridium difficile are increasingly reported. This microbe, previously associated mainly with nosocomial infections treated with intensive antibiotic therapy, is now also responsible for community-acquired infections in children. C. difficile is also the main cause of severe diarrhoea in some chronic diseases, such as inflammatory bowel diseases and cancer. Escherichia coli, Shigella spp., and Yersinia enterocolitica are the second most common cause of bacterial diarrhoea ${ }^{(1-4)}$.

Parasitic or protozoal infections caused by Giardia lamblia and Cryptosporidium rarely cause acute diarrhoea in immunocompetent children. These infections are often asymptomatic. Full-blown infections are usually seen in patients with immune deficiencies and those in developing countries $^{(1-4)}$.

The role of Candida in gastrointestinal infections is questionable. British studies showed that Candida does not cause diarrhoea in well-nourished children with no comorbidities $^{(4,5)}$.

According to the current ESPGHAN/ESPID recommendations, there is usually no need to determine the aetiology, which has generally no effects on the therapeutic management. However, diagnostic microbiology may be considered in children with chronic diseases (e.g. cancer or inflammatory bowel diseases), patients in severe condition or those with prolonged symptoms, who require specific treatment. Faecal microbiology should be absolutely per- and determination of the source of infection may be beneficial for the general population. Determination of disease aetiology may be also very useful in children with severe, bloody diarrhoea or those returning from an exotic trip to high-risk regions ${ }^{(1,2)}$.

The severity of the clinical symptoms of the disease depends to a large extent on patient's individual susceptibility, the aetiology of the infection and patient's age. Diarrhoea can be short-term and mild, but it may also lead to life-threatening severe water-electrolyte and acid-base disorders.

According to ESPGHAN/ESPID, there is no single clinical feature that may suggest a bacterial vs. viral aetiology. However, high fever $\left(>40^{\circ} \mathrm{C}\right)$, overt faecal blood, frequent low volume diarrhoea, abdominal pain and signs of central nervous system involvement suggest bacterial infection. Vomiting and respiratory symptoms, on the other hand, are more commonly seen in viral infections. Acute rotavirus diarrhoea is characterised by the most severe course, a higher number of diarrhoeic episodes and longer duration with a tendency to persist ${ }^{(1,3)}$.

The treatment of acute diarrhoea is based on the administration of oral rehydration solution (ORS) (50-60 mmol/L). Absolute indications for inpatient intravenous fluid replacement include shock, dehydration with impaired consciousness or severe acidosis, worsening of dehydration or lack of improvement despite oral/ tube rehydration therapy, severe abdominal distension or gastrointestinal obstruction. Isotonic crystalloid fluids, such as $0.9 \% \mathrm{NaCl}$ or Ringer's lactate solution, are used for intravenous fluid replacement. The rate of fluid administration depends on the severity of dehydration and the clinical status of the patient. Experts recommend rapid IV fluid infusion (3-6 hours), followed by resumption of oral rehydration ${ }^{(1,3,6)}$.

In the case of infants with the symptoms of acute infectious diarrhoea, breastfeeding should be continued throughout rehydration therapy. In older children, age-appropriate diet should be continued during or immediately after the initial rehydration phase ${ }^{(1,3,6)}$.

\section{AIM}

The aim of the paper was to assess the aetiology and the clinical course of acute gastroenteritis in children hospitalised in the Department of Paediatrics, Paediatric Nephrology and Allergology of the Military Institute of Medicine in 2018.

\section{MATERIALS AND METHODS}

We retrospectively analysed medical records of children hospitalised in the Department of Paediatrics, Paediatric Nephrology and Allergology of the Military Institute of Medicine between January and December 2018 due to gastroenteritis. 


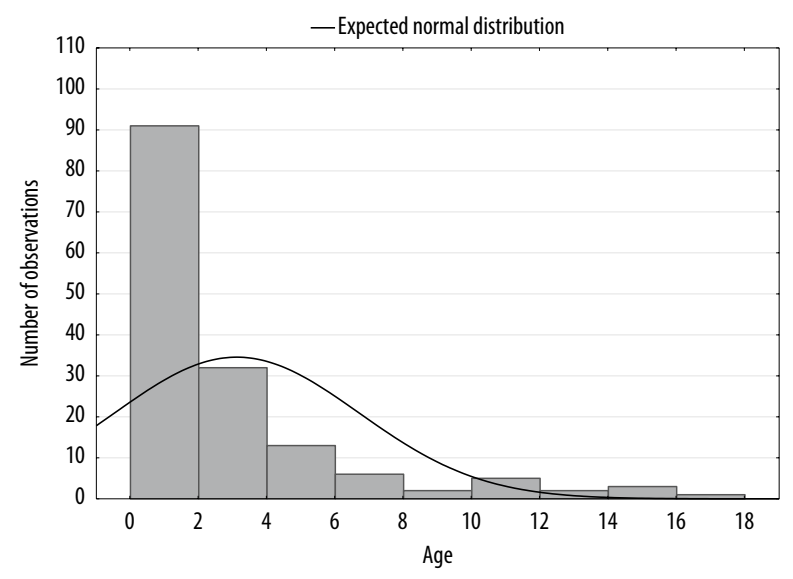

Fig. 1. An analysis of the age distribution in children hospitalised for gastroenteritis

We assessed medical histories of children hospitalised in the Department in 2018. Children diagnosed with acute gastroenteritis who had microbiological stool analysis for rota-, adeno- and norovirus antigens as well as faecal culture for Salmonella spp., Shigella spp. and Yersinia spp. performed were included in the study group. Ultimately, 155 children (84 girls and 71 boys) were qualified for the analysis, which accounted for $7 \%$ of all hospitalisations.

We performed a detailed analysis of data on the aetiology of gastroenteritis and laboratory parameters [white blood cell count, C-reactive protein (CRP), sodium and potassium levels, transaminase activity, capillary blood $\mathrm{pH}$ and base deficit in capillary blood]. We also considered symptoms due to which the patients reported to the Department.

The obtained data were analysed statistically using Statistica 12.0 software. A preliminary verification of data using a distribution normality plot was performed before the analysis. Final verification was performed using the Kolmogorov-Smirnov and Lilliefors normality test. Considering the lack of compliance with normal

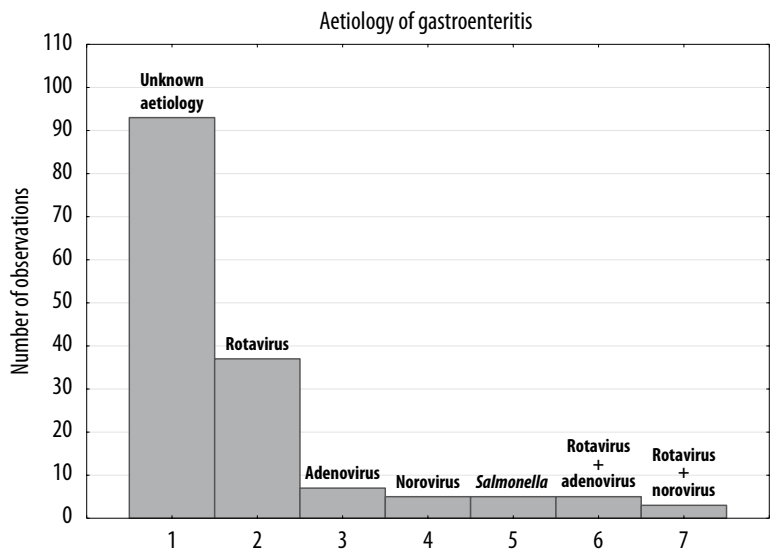

Fig. 2. Aetiology of gastroenteritis in children hospitalised in the Department of Paediatrics, Paediatric Nephrology and Allergology in 2018 distribution for selected variables, non-parametric tests that did not require normal distribution were used for statistical analysis in these cases. Student's $t$-test was used to evaluate variables with normal distribution. For correlation analysis, the Spearman rank coefficient was calculated for variables without a normal distribution, and Pearson's linear correlation coefficient was used for variables with a normal distribution. A $p$-value $<0.05$ was considered statistically significant.

\section{RESULTS}

\section{Age}

The median age in the study group was 2 years $\left(Q_{25}-1, Q_{75}-4\right)$. Most children were aged $\leq 2$ years (91/155). A detailed analysis of the age distribution is shown in Fig. 1.

\section{Aetiology}

Gastroenteritis of unknown aetiology was diagnosed in 93 children. Rotaviral, adenoviral and noroviral aetiology was identified in 37, 7, and 5 patients, respectively. Faecal culture positive for Salmonella spp. was reported for 5 children. Furthermore, mixed aetiology (rotaviral/adenoviral in 5 , and rotaviral/noroviral in 3 patients) was identified in 8 children (Fig. 2).

Rotaviruses were the most common aetiology of gastroenteritis in children $\leq 2$ years of age (Tab. 1 ).

\section{Symptoms}

Vomiting was the only symptom in 48 patients, diarrhoea in 40 patients, whereas 67 children presented with both these symptoms (Fig. 3).

\begin{tabular}{|l|c|c|c|c|}
\hline Aetiology & Number & $\begin{array}{c}\text { Cumulative } \\
\text { number }\end{array}$ & Percentage & $\begin{array}{c}\text { Cumulative } \\
\text { percentage }\end{array}$ \\
\hline \multicolumn{5}{|c|}{$\leq \mathbf{2}$ years } \\
\hline Unknown & 49 & 49 & 54 & 54 \\
\hline Rotavirus & 27 & 76 & 30 & 84 \\
\hline Adenovirus & 4 & 80 & 4 & 88 \\
\hline Norovirus & 4 & 84 & 4 & 92 \\
\hline Salmonella & 1 & 84 & 1 & 93 \\
\hline Mixed & 6 & 91 & 7 & 100 \\
\hline \multicolumn{5}{|c|}{$>\mathbf{2}$ years } \\
\hline Unknown & 44 & 44 & 69 & 69 \\
\hline Rotavirus & 10 & 54 & 16 & 84 \\
\hline Adenovirus & 3 & 57 & 5 & 89 \\
\hline Norovirus & 1 & 58 & 2 & 91 \\
\hline Salmonella & 4 & 62 & 6 & 97 \\
\hline Mixed & 2 & 64 & 3 & 100 \\
\hline
\end{tabular}

Tab. 1. The aetiology of gastroenteritis depending on age (in children aged $\leq 2$ years and $>2$ years) 


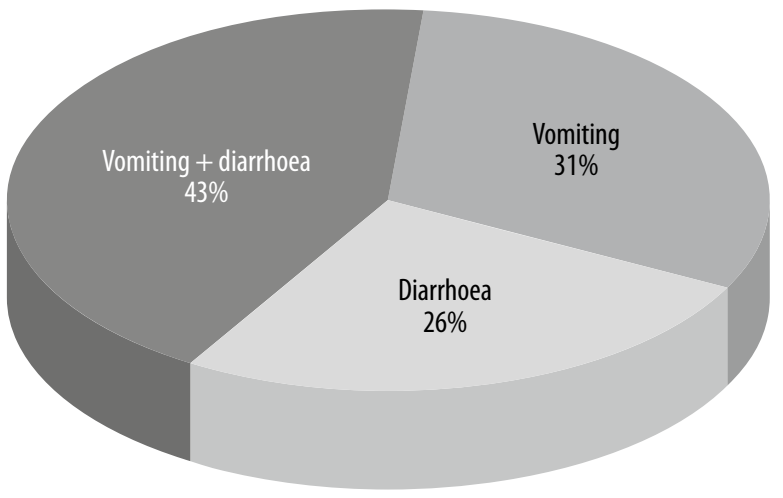

Fig. 3. Symptoms at admission

\section{Biochemical parameters}

The values of the analysed biochemical parameters are shown in Tab. 2.

Increased CRP is detected in adenoviral and Salmonella spp. infections (Fig. 4).

Considering the most common aetiology of gastroenteritis, i.e. rotaviral and adenoviral, it was found that lower CRP levels and higher aminotransferase levels were statistically more common in rotaviral infections (Figs. 5-7).

\section{DISCUSSION}

Acute gastroenteritis is one of the most common health problems in infants and small children. It is the second most common cause of hospital admissions to general paediatric units after pneumonia ${ }^{(7)}$. It is estimated that up to one in five children are admitted to hospital due to acute gastroenteritis $^{(8,9)}$. However, these rates were lower in our research, i.e. $7 \%$ of all hospital admissions, which is probably due the fact that in addition to general paediatrics, our Department is also involved in specialised diagnosis.

The pathogenesis of acute diarrhoea differs depending on the latitude and the economic status of a given region. Parasitic and bacterial diarrhoeas are more common in developing vs developed countries ${ }^{(10)}$. However, it is estimated that viral infections are the main cause of acute gastroenteritis in children globally, accounting for about $70 \%$ of all cases ${ }^{(11)}$. In our study, bacterial infections accounted for only $1 \%$ of cases among children $\leq 2$ years of age and

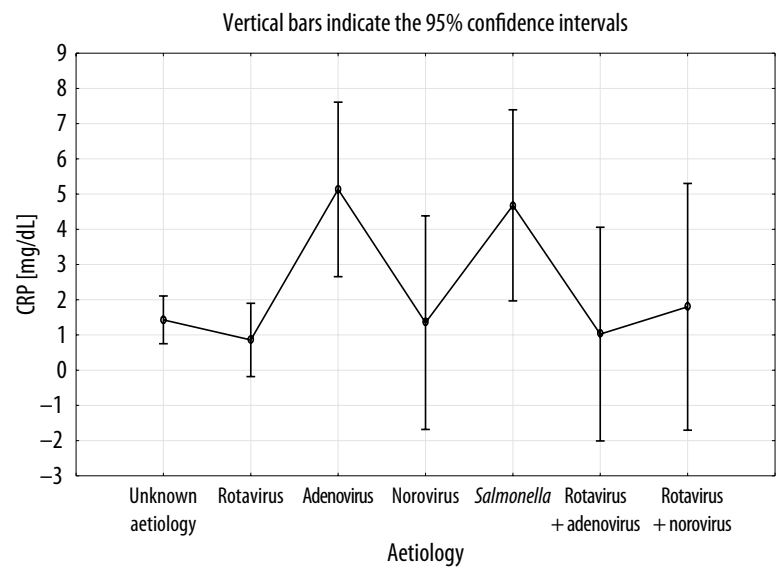

Fig. 4. C-reactive protein levels depending on the aetiology of gastroenteritis

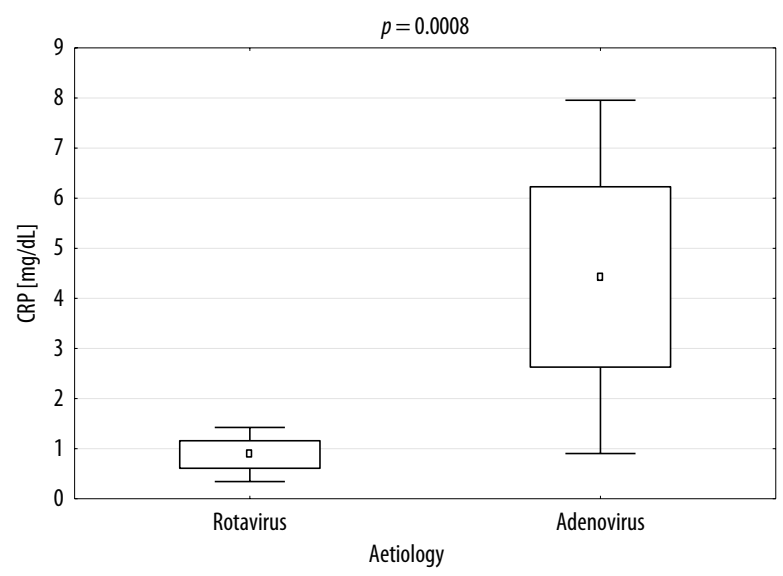

Fig. 5. CRP levels in rotaviral and adenoviral infection

$6 \%$ among children $>2$ years of age. The aetiology of acute gastroenteritis could not be determined in a large proportion of patients in both groups ( $54 \%$ of children $\leq 2$ years of age and $69 \%$ of children $>2$ years of age). These cases could be caused by viral, bacterial or parasitic agents. Since the introduction of molecular biology techniques [polymerase chain reaction (PCR), reverse-transcription polymerase chain reaction (RT-PCR)] in the late 1990s, multiple pathogens responsible for acute diarrhoea have been identified ${ }^{(12)}$. However, not all diagnostic techniques are widely used in Poland, mainly for financial reasons,

\begin{tabular}{|l|c|c|c|c|c|}
\hline Variable & Unknown aetiology & Rotavirus & Adenovirus & Norovirus & Salmonella \\
\hline CRP [mg/dl] (median, $\left.q_{25}-q_{75}\right)$ & $3.8(0.2-9.8)$ & $0.2(0.1-0.7)$ & $3.8(0.2-9.8)$ & $0.3(0.3-0.5)$ & $4.4(4.4-4.7)$ \\
\hline WBC $\left[\times 10^{9} / \mu l\right]$ (median, $\left.q_{25}-q_{75}\right)$ & $13.1(10.4-15.9)$ & $8.6(7.5-12.3)$ & $13.1(10.4-15.9)$ & $6.6(6.2-9.4)$ & $7.7(6.9-15.3)$ \\
\hline AST [U/l] (median, $\left.q_{25}-q_{75}\right)$ & $38.5(28.0-44.0)$ & $58.0(34.6-75.8)$ & $38.5(28.0-44.0)$ & $61.0(40.0-61.0)$ & $26.0(25.0-29.0)$ \\
\hline ALT [U/I] (median, $\left.q_{25}-q_{75}\right)$ & $14.0(11.0-20.0)$ & $30.0(22.0-38.0)$ & $14.0(11.0-20.0)$ & $20.5(12.0-39.0)$ & $14.0(13.0-17.0)$ \\
\hline pH (median, $\left.q_{25}-q_{75}\right)$ & $7.4(7.4-7.5)$ & $7.4(7.3-7.4)$ & $7.4(7.4-7.5)$ & $7.3(7.3-7.4)$ & $7.4(7.4-7.5)$ \\
\hline Na [mmol/l] (median, $\left.q_{25}-q_{75}\right)$ & $139.0(137.0-141.0)$ & $138.0(135.0-139.0)$ & $138.0(13.60-140.0)$ & $141.0(138.0-142.0)$ & $137.0(133.0-137.0)$ \\
\hline K [mmol/l] (median, $\left.q_{25}-q_{75}\right)$ & $4.5(4.2-4.7)$ & $4.3(4.2-4.9)$ & $4.4(4.2-4.5)$ & $4.6(4.4-5.0)$ & $4.2(3.8-4.6)$ \\
\hline CRP - C-reactive protein; WBC- white blood cells; AST - aspartate transaminase; ALT - alanine transaminase; Na - sodium; K - potassium. \\
\hline
\end{tabular}




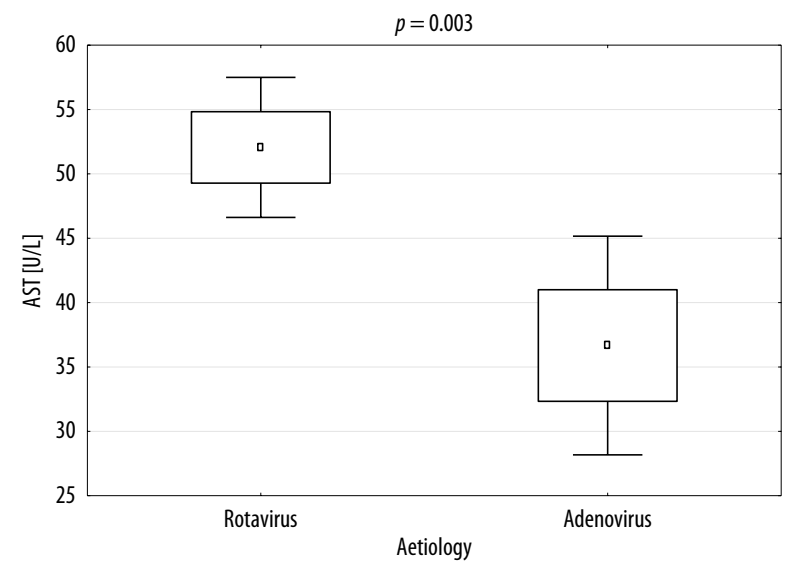

Fig. 6. Aspartate aminotransferase (AST) levels in rotaviral and adenoviral infection

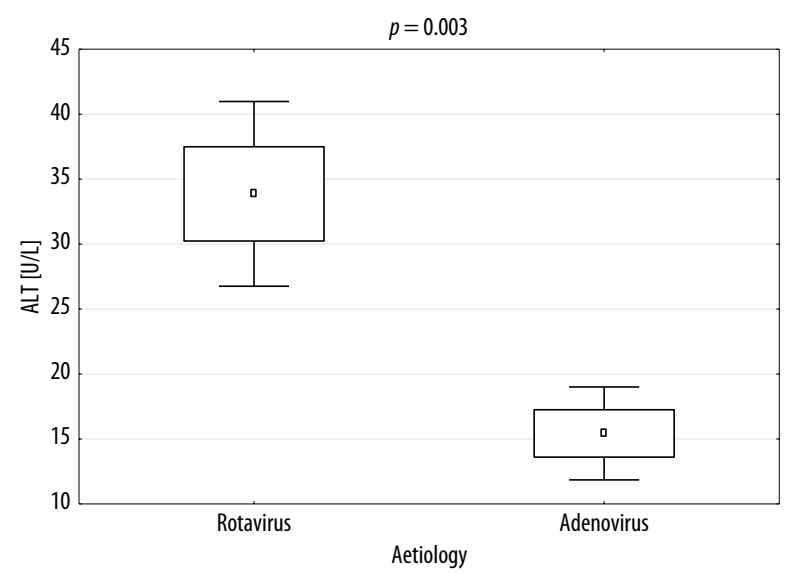

Fig. 7. Alanine aminotransferase (ALT) levels in rotaviral and adenoviral infection

which may account for the high incidence of infections of unknown aetiology.

Children aged $\leq 2$ years dominated in the study group, which is most likely due to gastrointestinal immaturity, especially in infancy. In the first year of life, only small amounts of hydrochloric acid and digestive enzymes are secreted in the stomach, and the mucous membrane is delicate and susceptible to infections. Intestinal mucosa also shows low enzymatic activity and increased permeability, which promotes diarrhoea ${ }^{(13)}$.

It should be noted that the risk group for acute diarrhoea primarily includes malnourished, formula-fed and prematurely born children ${ }^{(14)}$.

In our study, rotaviral infections were the most common cause of acute gastroenteritis in children $\leq 2$ years of age, accounting for $30 \%$ of all cases. Although slightly lower rates were reported for older children (16\%), this was still the leading cause of acute gastroenteritis in children aged $>2$ years. Similar results were obtained by German researchers, who analysed hospital admissions for acute diarrhoea in children aged between 0 and 10 years over a 6-year period. They showed that rotavirus, which accounted for nearly $30 \%$ of all cases, was the most common pathogen in this age group ${ }^{(15)}$.
A similar tendency is observed in Poland; according to the National Institute of Public Health - National Institute of Hygiene, rotaviral infection is the most common aetiology of acute diarrhoea in each age group ${ }^{(3)}$.

Laboratory findings for acute gastroenteritis vary depending on the aetiology. Our study showed significantly higher CRP levels in adenoviral vs. rotaviral infections. A reverse trend was observed for hepatic transaminase levels - increased serum aspartate transaminase (AST) and alanine transaminase (ALT) levels were observed in rotaviral infections. Similar observations were presented by Salamon-Słowińska, who analysed cases of acute diarrhoea in children $<5$ years of age. Observations in a group of 534 children hospitalised in one of hospitals in Poznań due to acute viral diarrhoea showed lower mean CRP and higher hepatic transaminases in rotaviral infections compared to other pathogens (including bacteria) $^{(16)}$.

Elevated hepatic transaminases in rotaviral gastroenteritis in our study correspond with the reports of many other researchers ${ }^{(7,17,18)}$, and may indicate viral transmission not only through the gastrointestinal tract, but also through blood, leading to the involvement of other organs, such as the liver. In their experimental study, Crawford et al. observed histological lesions in the liver and lungs of rats infected with rotavirus, which indicates involvement of these organs ${ }^{(19)}$. However, it should be emphasised that hypertransaminasemia associated with rotaviral infection is generally transient and is not accompanied by signs of liver damage ${ }^{(20)}$.

The clinical course of gastroenteritis differs depending on the age of patients. In our study, children $\leq 2$ years of age developed both diarrhoea and vomiting, whereas vomiting was the dominant symptom in older children. No electrolyte disturbances or significant or acid-base imbalances were seen in the course of infections in our centre, which may be due to the rapid implementation of appropriate therapy. However, it should be remembered that in addition to the most common symptoms such as diarrhoea or vomiting, rotaviral acute gastroenteritis can cause severe extraintestinal complications, such as convulsions and myositis ${ }^{(21,22)}$. It is worth emphasising that vaccinations, which protect especially against severe infection, are the most effective form of preventing rotaviral infections. However, vaccination coverage for infants is still low in Poland, i.e. 5-10\%(23).

\section{CONCLUSIONS}

Rotaviruses were the most common aetiology in the total study group. The clinical picture of rotaviral infection was dominated by vomiting and diarrhoea, accompanied by transient hypertransaminasemia.

\section{Conflict of interest}

The authors do not report any financial or personal connections with other persons or organisations, which might negatively affect the contents of this publication and/or claim authorship rights to this publication. 


\section{References}

1. Guarino A, Ashkenazi S, Gendrel D et al.; European Society for Pediatric Gastroenterology, Hepatology, and Nutrition; European Society for Pediatric Infectious Diseases: European Society for Pediatric Gastroenterology, Hepatology, and Nutrition/European Society for Pediatric Infectious Diseases evidence-based guidelines for the management of acute gastroenteritis in children in Europe: update 2014. J Pediatr Gastroenterol Nutr 2014; 59: 132-152.

2. Shane AL, Mody RK, Crump JA et al.: 2017 Infectious Diseases Society of America clinical practice guidelines for the diagnosis and management of infectious diarrhea. Clin Infect Dis 2017; 65: 1963-1973.

3. Falszewska A, Szajewska H: Ostra biegunka infekcyjna u dzieci co mówią aktualne dane? Zakażenia XXI wieku 2018; 1: 79-87.

4. Buda P, Książyk J: Ostra biegunka u dzieci. Pediatr Med Rodz 2010; 6: 275-282.

5. Forbes D, Ee L, Camer-Pesci P et al.: Faecal candida and diarrhoea. Arch Dis Child 2001; 84: 328-331.

6. Whyte LA, Al-Araji RA, McLoughlin LM: Guidelines for the management of acute gastroenteritis in children in Europe. Arch Dis Child Educ Pract Ed 2015; 100: 308-312.

7. Rytlewska M, Bako W, Ratajczak B et al.: Epidemiological and clinical characteristics of rotaviral diarrhoea in children from Gdańsk, Gdynia and Sopot. Med Sci Monit 2000; 6: 117-122.

8. Jankowska-Folusiak J, Dębicki L, Zeman K: Analiza hospitalizacji na oddziale pediatrycznym szpitala wojewódzkiego ze szczególnym uwzględnieniem chorób dolnych dróg oddechowych. Pediatr Med Rodz 2016; 12: 310-317.

9. Mielewczyk-Małecka M: Diagnostyka i leczenie biegunek ostrych u dzieci w warunkach szpitala powiatowego w latach 2006-2010. Rozprawa doktorska, 2012.

10. O'Ryan GM, Ashkenazi-Hoffnung L, O'Ryan-Soriano MA et al.: Management of acute infectious diarrhea for children living in resource-limited settings. Expert Rev Anti Infect Ther 2014; 12: 621-632.

11. Chow CM, Leung AK, Hon KL: Acute gastroenteritis: from guidelines to real life. Clin Exp Gastroenterol 2010; 3: 97-112.

12. Ołdak E, Sulik A, Rożkiewicz D et al.: Ostre biegunki wirusowe u dzieci. Wiad Lek 2006; 59: 534-537.
13. Stadnicka SK, Brodowicz-Król M, Trojanowska A et al.: Analiza przyczyn biegunki ostrej u niemowląt jako wyznacznik profilaktyki pierwotnej i wtórnej. J Educ Health Sport 2016; 6 (7): 91-102.

14. Szymański $\mathrm{H}$, Pejcz J, Jawień $M$ et al.: Treatment of acute infectious diarrhoea in infants and children with a mixture of three Lactobacillus rhamnosus strains - a randomized, double-blind, placebo-controlled trial. Aliment Pharmacol Ther 2006; 23: 247-253.

15. Kowalzik F, Zepp F, Hoffmann I et al.: Disease burden of rotavirus gastroenteritis in children residing in Germany: a retrospective, hospital-based surveillance. Pediatr Infect Dis J 2016; 35 : $97-103$.

16. Salamon-Słowińska D: Ostre biegunki u dzieci poniżej 5. roku życia - aspekty kliniczne i epidemiologiczne. Rozprawa doktorska, 2008.

17. Akelma AZ, Kütükoğlu I, Köksal T et al.: Serum transaminase elevation in children with rotavirus gastroenteritis: seven years' experience. Scand J Infect Dis 2013; 45: 362-367.

18. Chiappini E, Azzari C, Moriondo M et al.: Viraemia is a common finding in immunocompetent children with rotavirus infection. J Med Virol 2005; 76: 265-267.

19. Crawford SE, Patel DG, Cheng E et al.: Rotavirus viremia and extraintestinal viral infection in the neonatal rat model. J Virol 2006; 80: 4820-4832.

20. Smukalska E, Pawłowska M, Kozielewicz D et al.: Podwyższona aktywność AlAT w przebiegu biegunki wywołanej przez rotawirusy. Przegl Epidemiol 2008; 62: 107-112.

21. Kim BR, Choi GE, Kim YO et al.: Incidence and characteristics of norovirus-associated benign convulsions with mild gastroenteritis, in comparison with rotavirus ones. Brain Dev 2018; 40: 699-706.

22. Trivedi M, Jain A, Shah D et al.: Rotavirus gastroenteritis associated with encephalopathy, myositis, transaminitis and hypoalbuminemia. Indian J Pediatr 2019; 86: 642-644.

23. Pulkowska-Nowocień A, Prędota D, Topczewska-Cabanek A et al.: Stan zaszczepienia dzieci przeciw rotawirusom $\mathrm{w}$ wybranej poradni Podstawowej Opieki Zdrowotnej w Warszawie w latach 2006-2013. Fam Med Primary Care Rev 2014; 16: 353-355. 